\title{
Determinants of Stunting Prevention among Mothers with Children Aged 6-24 Months
}

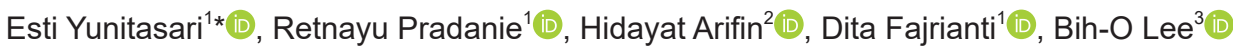 \\ ${ }^{1}$ Department of Fundamental Nursing, Faculty of Nursing, Universitas Airlangga, Surabaya, Indonesia; ${ }^{2}$ Department of Medical-Surgical \\ Nursing, Universitas Padjadjaran, Bandung, Indonesia; ${ }^{3}$ College of Nursing, Kaohsiung Medical University, Kaohsiung, Taiwan
}

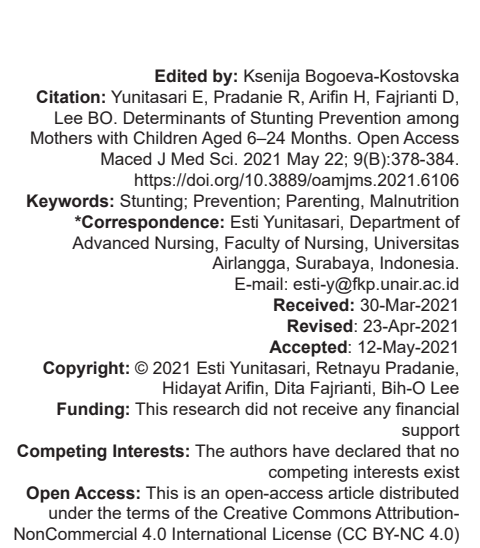

\section{Abstract}

AIM: The purpose of this study was to analyze the determinants of stunting prevention in relation to mothers with children aged 6-24 months in Madura Indonesia.

METHODS: The design of this study was cross-sectional. The number of samples totaled 109 respondents using a purposive sampling technique. The independent variables were knowledge, attitudes, income, cultural values, and parenting. The dependent variable was stunting prevention. The data were collected using a questionnaire and then analyzed using the Chi-square test with a significance level of $\alpha<0.05$.

RESULTS: The factors associated with stunting prevention were knowledge ( $p=0.007)$, attitude $(p=0.034)$, income $(p=0.006)$, cultural values $(p=0.016)$, and parenting patterns $(p=0.000)$

CONCLUSIONS: Knowledge, attitude, income, cultural values, and parenting influenced the parent's strategy when it came to prevent stunting in their children. Stunting prevention programs should focus on improving parental behavior by modifying these factors.

\section{Introduction}

Stunting in toddlers needs special attention because it has an impact on the inhibition of physical growth, mental development, and the overall health status of children [1]. Indonesia is the third highest country with stunting in children under five in Southeast Asia, and East Java is one of the provinces with a high number of stunting cases. The proportion of stunting in East Java is 27.5\% [2]. One of the Public Health Center (PHC) working areas in Madura has a $47.27 \%$ incidence rate of stunting [3]. Maternal behavior and culture in Madura showed that exclusive breastfeeding is not given until the first 6-month, complementary feeding is given faster, such as bananas, rice cake, and porridge and most of mothers were married in young age. In addition, the low hygiene behavior in the Madurese community is also became a problem by the prevalence of $18.2 \%$ with the target $65 \%$ [4].

Stunting is caused by two groups' factors, specifically direct factors and indirect factors. The direct cause of stunting is a nutritional intake that is not appropriate when it comes to meeting the needs of the child [5]. The indirect cause of stunting is parenting [6]. Parenting practices include child health care, dietary diversity, stimulation, depressive symptoms, maternal knowledge about child development, and sociodemographic and family indicators [7]. Problems in relation to exclusive breastfeeding, a lack of stimulation of the child's psychosocial development, wrong feeding practices, poor sanitation practices, and poor child health care and inadequate immunization are the causes of stunting [8]. The interaction between the mother and baby through breastfeeding will help the child to have stable emotions and better social development [9]. The practice of feeding children is essential because it will influence the child's growth. Besides that, sanitation practices also play an important role in child growth. Poor sanitation and a dirty environment will make it easier for the children to get infections that allow the children to have diarrhea, threatening them with stunting as a result [10]. Stunting in children will have an impact on their productivity in adulthood. Stunted children also experience difficulties when learning to read, have the potential for imperfect growth and development, have lower motor skills and productivity, and a high risk of suffering from noncommunicable diseases [11].

A study conducted by Aramico et al. showed that poor parenting resulted in 8 times greater risk of stunting in children. Inadequate forms of parenting 
include incomplete immunization, not providing exclusive breastfeeding, poor personal hygiene, and poor environmental sanitation [12]. Parenting practices are focused on improving nutrition, hygiene, and stimulation [7]. In this study, the knowledge of the mother about stunting, attitude, income, and her cultural values was researched to gain more information about the factors related to stunting. We observed those variables because it has not been done much in Indonesia, especially in Madura. In addition, with the demographic and cultural characteristics that exist in the community, those variables can provide new information related to the incidence of stunting. Thus, the study aimed to analyze the determinants of stunting prevention in relation to mothers with children aged 6-24 months.

\section{Method}

\section{Design}

This research was an analytic observational study with a cross-sectional approach.

\section{Settings}

The study was conducted from March to June 2020. The sample consisted of 109 mothers attending a PHC in Madura, Indonesia. The sample was obtained through a purposive sampling technique and using Slovin Formula [13]. The inclusion criteria were mothers with children aged 6-24 months who were living together with their children and were able to read and write. The exclusion criteria were mothers whose children have diseases that can affect the child's development (congenital heart disease, kidney disease, leukemia, HIVIAIDS, neurological diseases, diabetes mellitus, and mental disorders). Then, we collected the data using questionnaires to respondents.

\section{Variable}

The independent variables were the mother's age, family type, mother's education, father's work, mother's work, the total of living children, children's age, children's gender, immunization status, knowledge, attitudes, income, cultural values, and parenting. The dependent variable was stunting prevention.

The mother's age was classified based on the age categories used in Indonesia, specifically 19-20 years old, 30-39 years old, and $40-50$ years [14]. Furthermore, family type was divided into core family and big family [15]. The mother's education level refers to the Indonesian government regulations which were divided into no education, elementary school, junior high school, senior high school, and university [16]. The father's work in this study was divided into three categories, namely daily workers, entrepreneurs, and employees [17]. The mother's work was categorized into no work, daily workers, entrepreneurs, and employees [18], [19]. The total of living children was divided into four categories, namely $1->3$ children [17]. The children's age was divided into three categories, namely 6-12 months old, 13-18 months old, and 19-24 months old. The children's gender was divided into male and female categories [20]. Immunization was categorized into 2 groups, namely had completed getting the basic immunization and incomplete, for those who did not get complete immunization [20], [21].

The knowledge questionnaire was developed by the researcher. The 15 questions consist of definitions, causes, signs and symptoms, effects, and the prevention of stunting. The questionnaire responses were divided into three categories: good (76-100\%), enough (56-75\%), and less $(\leq 55 \%)$. The Cronbach's alpha score was 0.917 .

The attitude questionnaire included a statement of reaction, specifically the mother's response to stunting prevention which consisted of 10 questions. The questionnaire was adopted from the work of Kemenkes [22], Sundari and Nuryanto [23], and the World Health Organization [24]. A Likert scale from strongly disagree to strongly agree was used. A positive score attitude was determined if the value $\geq$ mean (mean $=29$ ) and a negative if the value $<$ mean (mean $=29$ ). The Cronbach's alpha score was 0.910.

The cultural values questionnaire included questions about the habits carried out by the mothers when caring for the children, and the questionnaire was tested for validity and reliability. In total, it consisted of 10 questions. The interview guide used a Likert scale with the answer choices of strongly agree, agree, disagree, and strongly disagree. A positive score was given if the value $\geq$ mean (mean $=26$ ) and a negative if the value $<$ mean (mean $=26$ ). The Cronbach's alpha score was 0.954 .

The parenting questionnaire included questions about the actions taken by the mothers in childcare to prevent stunting. This contained 15 questions as well as asking questions on the mother's love and attention when caring for the child, which consisted of 4 questions. The interview guidelines used a Likert scale with the answer choices of always, often, sometimes, and never. The good care was if the value $\geq$ mean (mean $=50)$ and poor care $<$ mean $($ mean $=50)$. The questionnaire was tested for validity and reliability before being distributed to the respondents. The Cronbach's alpha score was 0.974 .

The stunting prevention questionnaire included questions about the ways in which the mothers prevented 
stunting and it was tested for validity and reliability. It consisted of 6 questions. The questionnaire consisted of close-ended questions with a dichotomy question type with limited yes and no answers. The scores given were positive if the value $\geq$ mean (mean $=4.7$ ) and negative if the value $<$ mean (mean $=4.7$ ). The Cronbach's alpha score was 0.921 .

\section{Analysis}

The data analysis was conducted using the STATA 16.1 software. We used descriptive statistics to conduct the univariate analysis and the Chi-square test to conduct the bivariate analysis. The level of significance for the $p=0.05$.

\section{Ethical clearance}

This research conducted an ethical test at the Faculty of Nursing, Universitas Airlangga and passed the ethical review with code No 1940-KEPK on March 12, 2020.

\section{Results}

The demographic data of the respondents have been presented in Table 1. The data show that the majority of mothers in this study were aged 19-29 years old $(49.54 \%)$. More than half of the families in this study consisted of core families (65.14\%). From the data, the mother's last education was either no education $(33.94 \%)$ or elementary school $(33.03 \%)$. Almost all of the fathers worked as daily workers (48.62\%), while the majority of the mothers did not work (51.38\%). The majority of the living children in this study totaled $1(37.61 \%)$. Most of the children in this study were 19-24 months old $(39.45 \%)$, with the majority being male $(54.13 \%)$. The level of immunization coverage was $68.81 \%$. Nearly half of the respondents, in this case, had less knowledge about stunting prevention $(45.87 \%)$ with negative behaviors $(54.13 \%)$. The majority of the respondents had a total income of more than 1,900,000 (51.38\%). The respondents had a high rate for displaying negative cultural values $(50.46 \%)$. The respondents had scores that indicated less parenting $(53.21 \%)$ and the positive prevention of stunting (55.05\%).

Table 2 shows the bivariate analysis and the Chi-square test results. The results of the analysis show that knowledge $(p=0.007)$, attitude $(p=0.034)$, the respondent's income $(p=0.006)$, cultural values $(p=0.016)$, and parenting $(p=0.000)$ have a significant relationship with the prevention of stunting.
Table 1: Characteristics of the respondents $(n=109)$

\begin{tabular}{|c|c|c|}
\hline Characteristics & $\mathrm{n}$ & $\%$ \\
\hline \multicolumn{3}{|l|}{ Mother's age } \\
\hline $19-29$ & 54 & 49.54 \\
\hline $30-39$ & 38 & 34.86 \\
\hline $40-50$ & 17 & 15.60 \\
\hline \multicolumn{3}{|l|}{ Family type } \\
\hline Core family & 71 & 65.14 \\
\hline Big family & 38 & 34.86 \\
\hline \multicolumn{3}{|l|}{ Mother's education } \\
\hline No education & 37 & 33.94 \\
\hline Elementary school & 36 & 33.03 \\
\hline Junior high school & 19 & 17.43 \\
\hline Senior high school & 12 & 11.01 \\
\hline University & 5 & 4.59 \\
\hline \multicolumn{3}{|l|}{ Father's work } \\
\hline Daily worker & 53 & 48.62 \\
\hline Entrepreneur & 34 & 31.19 \\
\hline Employee & 22 & 20.18 \\
\hline \multicolumn{3}{|l|}{ Mother's work } \\
\hline No work & 56 & 51.38 \\
\hline Daily worker & 29 & 26.61 \\
\hline Entrepreneur & 16 & 14.68 \\
\hline Employee & 8 & 7.34 \\
\hline \multicolumn{3}{|l|}{ Total of living children } \\
\hline 1 & 41 & 37.61 \\
\hline 2 & 37 & 33.94 \\
\hline 3 & 15 & 13.76 \\
\hline$>3$ & 16 & 14.68 \\
\hline \multicolumn{3}{|l|}{ Children's age } \\
\hline 6-12 months & 39 & 35.78 \\
\hline $13-18$ months & 27 & 24.77 \\
\hline 19-24 months & 43 & 39.45 \\
\hline \multicolumn{3}{|l|}{ Children's gender } \\
\hline Male & 59 & 54.13 \\
\hline Female & 50 & 45.87 \\
\hline \multicolumn{3}{|l|}{ Immunization } \\
\hline Not complete & 34 & 31.19 \\
\hline Complete & 75 & 68.81 \\
\hline \multicolumn{3}{|l|}{ Knowledge } \\
\hline Less & 50 & 45.87 \\
\hline Enough & 41 & 37.61 \\
\hline Good & 18 & 16.51 \\
\hline \multicolumn{3}{|l|}{ Attitude } \\
\hline Negative & 59 & 54.13 \\
\hline Positive & 50 & 45.87 \\
\hline \multicolumn{3}{|l|}{ Income } \\
\hline$<1,900,000$ & 53 & 48.62 \\
\hline More than $1,900,000$ & 56 & 51.38 \\
\hline \multicolumn{3}{|l|}{ Cultural values } \\
\hline Negative & 55 & 50.46 \\
\hline Positive & 54 & 49.54 \\
\hline \multicolumn{3}{|l|}{ Parenting } \\
\hline Good & 51 & 46.79 \\
\hline Less & 58 & 53.21 \\
\hline \multicolumn{3}{|l|}{ Prevention of stunting } \\
\hline Negative & 49 & 44.95 \\
\hline Positive & 60 & 55.05 \\
\hline
\end{tabular}

\section{Discussion}

The distribution data show that most of the respondents, who have less knowledge, are unable to prevent stunting properly. Knowledge is the initial capital that the mothers use to provide adequate care to their children. The results show that knowledge has a significant correlation with the prevention of stunting, but here it had low relationship strength. A lack of comprehensive knowledge could therefore be one of the causes of stunting. Based on the distribution of the answers to the knowledge questionnaire, it is known that there are many mothers who do not understand the meaning of stunting, the manifestation of stunting, and the causes of stunting. This is especially so in terms of fulfilling the child's nutritional needs since pregnancy, exclusive breastfeeding for infants, and fulfilling their immunization regimen to prevent infection in children. In terms of preventing stunting, a mother must not only 
Table 2: Bivariate analysis of the determinants of stunting prevention among the mothers with children aged 6-24 months ( $n=109)$

\begin{tabular}{|c|c|c|c|c|c|c|}
\hline \multirow[t]{3}{*}{ Variables } & \multicolumn{4}{|c|}{ Prevention of stunting } & \multirow[t]{3}{*}{$\mathrm{X}^{2}$} & \multirow[t]{3}{*}{$\mathrm{p}$} \\
\hline & \multicolumn{2}{|c|}{ Negative } & \multicolumn{2}{|c|}{ Positive } & & \\
\hline & $\mathrm{n}$ & $\%$ & $\mathrm{n}$ & $\%$ & & \\
\hline \multicolumn{7}{|l|}{ Mother's age } \\
\hline $19-29$ & 22 & 20.18 & 32 & 29.36 & \multirow[t]{3}{*}{0.9152} & \multirow[t]{3}{*}{0.633} \\
\hline $30-39$ & 18 & 16.51 & 20 & 18.35 & & \\
\hline $40-50$ & 9 & 8.26 & 8 & 7.34 & & \\
\hline \multicolumn{7}{|l|}{ Family type } \\
\hline Core family & 34 & 31.19 & 37 & 33.94 & \multirow[t]{2}{*}{0.7081} & \multirow[t]{2}{*}{0.400} \\
\hline Big family & 15 & 13.76 & 23 & 21.10 & & \\
\hline \multicolumn{7}{|l|}{ Mother's education } \\
\hline No education & 13 & 11.93 & 24 & 22.02 & \multirow[t]{5}{*}{6.0002} & \multirow[t]{5}{*}{0.199} \\
\hline Elementary school & 15 & 13.76 & 21 & 19.27 & & \\
\hline Junior high school & 13 & 11.93 & 6 & 5.50 & & \\
\hline Senior high school & 6 & 5.50 & 6 & 5.50 & & \\
\hline University & 2 & 1.83 & 3 & 2.75 & & \\
\hline \multicolumn{7}{|l|}{ Father's work } \\
\hline Daily worker & 23 & 21.10 & 30 & 27.52 & \multirow[t]{3}{*}{0.1151} & \multirow[t]{3}{*}{0.944} \\
\hline Entrepreneur & 16 & 14.68 & 18 & 16.51 & & \\
\hline Employee & 10 & 9.17 & 12 & 11.01 & & \\
\hline Mother's work & & & & & & \\
\hline No work & 28 & 25.69 & 28 & 25.69 & 1.9703 & 0.579 \\
\hline Daily worker & 13 & 11.93 & 16 & 14.68 & & \\
\hline Entrepreneur & 5 & 4.59 & 11 & 10.09 & & \\
\hline Employee & 3 & 2.75 & 5 & 4.59 & & \\
\hline Total of living children & & & & & & \\
\hline 1 & 19 & 17.43 & 22 & 20.18 & 1.0298 & 0.794 \\
\hline 2 & 17 & 15.60 & 20 & 18.35 & & \\
\hline 3 & 5 & 4.59 & 10 & 9.17 & & \\
\hline$>3$ & 8 & 7.34 & 8 & 7.34 & & \\
\hline Children's age & & & & & & \\
\hline 6-12 months & 16 & 14.68 & 23 & 21.10 & 1.6358 & 0.441 \\
\hline $13-18$ months & 15 & 13.76 & 12 & 11.01 & & \\
\hline 19-24 months & 18 & 16.51 & 25 & 22.94 & & \\
\hline Children's gender & & & & & & \\
\hline Male & 25 & 22.94 & 34 & 31.19 & 0.3463 & 0.556 \\
\hline Female & 24 & 22.02 & 26 & 23.85 & & \\
\hline Immunization & & & & & & \\
\hline Not complete & 16 & 14.68 & 18 & 16.51 & 0.0885 & 0.766 \\
\hline Complete & 33 & 30.28 & 42 & 38.53 & & \\
\hline Knowledge & & & & & & \\
\hline Less & 30 & 27.52 & 20 & 18.35 & 10.0190 & $0.007^{\star \star \star}$ \\
\hline Enough & 11 & 10.09 & 30 & 27.52 & & \\
\hline Good & 8 & 7.34 & 10 & 9.17 & & \\
\hline Attitude & & & & & & \\
\hline Negative & 32 & 29.36 & 27 & 24.77 & 4.4793 & $0.034^{\star *}$ \\
\hline Positive & 17 & 15.60 & 33 & 30.28 & & \\
\hline Income & & & & & & \\
\hline$<1,900,000$ & 31 & 28.44 & 22 & 20.18 & 7.6389 & $0.006^{\star \star *}$ \\
\hline More than $1,900,000$ & 18 & 16.51 & 38 & 34.86 & & \\
\hline Cultural values & & & & & & \\
\hline Negative & 31 & 28.44 & 24 & 22.02 & 5.8403 & $0.016^{\star \star}$ \\
\hline Positive & 18 & 16.51 & 36 & 33.03 & & \\
\hline Parenting & & & & & & \\
\hline Good & 48 & 44.04 & 3 & 2.75 & 93.6182 & $0.000^{\star \star \star}$ \\
\hline Less & 1 & 0.92 & 57 & 52.29 & & \\
\hline
\end{tabular}

possess knowledge about feeding practice but also children's growth and development as well because it could help them to monitor their child's health. Children with good parenting will grow well [25].

Knowledge itself is influenced by many factors, one of which is the level of education and age [26]. This research is in line with the research conducted by Aridiyah and Rohmawati [27] and Kassie and Workie [28]. The studies stated that one of the factors that influence the occurrence of stunting in children is the mother's education and knowledge. Mothers who are highly educated have better knowledge about their child's nutritional health, are more aware of their child's health, and provide better parenting. It can be concluded that the higher the education of the mother, the better the mother's knowledge about their child's health status and the lower the incidence of child stunting. The demographic data of the respondents indicate that most of the mothers in the District of Proppo only graduated from elementary school. In addition, the majority of mothers were in early adulthood. The older a person is, the better their mental development process is as their ability to learn and think increases. They can better adapt to new situations [29]. Mothers of a young age follow orders or suggestions from others, while in the final adult phase, they are considered to be more capable of good parenting.

The results show that there is a significant relationship between attitude and the prevention of stunting with a low correlation. Most of the respondents have a negative attitude with less stunting prevention care as a result. In terms of the distribution of the respondents' answers for the attitude component, it appears that there are still respondents who have negative attitudes about exclusive breastfeeding and the fulfillment of balanced nutrition from the completion of pregnancy in order to prevent stunting. This is consistent with the research conducted by Olsa et al., [30] Septamarini et al., [31], and Utami et al., [32] which states that there is a significant relationship between maternal parenting attitude and the incidence of stunting. The attitude of the mothers who are lacking in good child feeding practices will have an impact on the child's growth in the long term. The mother's attitude toward childcare will affect the child's health status. A good mother's attitude will be followed by the incidence of stunting decreased.

The results of the distribution of the answers to the attitude variable show that there are indicators that do not support parenting, namely responding and appreciating. The respondents consider that washing their hands is not necessary. This is one of the factors that cause children to become easily infected and this will affect their growth and development. The respondents also stated that complementary foods given to children are any food that can make the children full. If the food given to the child has poor nutritional content, this can cause the child to be malnourished and this will hinder their growth process.

The results showed that there was a significant relationship between income and the prevention of stunting. The respondents who had a high income engaged stunting prevention well, as was found for 38 respondents (34.9\%). This study is in line with the research by Aryastami et al., [33], Beal et al., [34], Cetthakrikul et al., [35], and Utami et al., [32]. The study states that the economic status of the household is related to the occurrence of stunting. Families with an income below the regional minimum wage are unable to meet the complementary food needs related to the children's breastfeeding, meaning that the children's nutrition cannot be fulfilled. A high family income is a form of support and protection that can prevent stunting because, with a high income, the families can provide complementary foods alongside breastfeeding according to the children's need for fulfilled nutrition. This low economic status leads to low birth weight and 
prolonged stunting. Low-income families are one of the factors involved in the occurrence of under-nutrition, hampering their growth.

Low-income families often cannot afford healthy and balanced nutritional food because the income that they get only meets their minimal needs [32]. Apart from the families being unable to provide healthy and nutritious food for the children, the home environment factor also affects the occurrence of stunting. A low-income family environment is less clean and has inadequate ventilation, which can inhibit the growth of any children. Most of the respondents worked as day laborers where the household income is low or less than the regional minimum wage. Income is the spearhead for meeting one's life needs. If the family income is high, then all household needs can be met [32]. A high income will affect the practice of feeding children, stimulate the children's psychosocial development, and allow them to visit the necessary health facilities to monitor their children's health [33]. If this is done correctly, the child's health will always be monitored so then the incidence of stunting can be prevented.

The results showed that there was a significant relationship between cultural values and the prevention of stunting. Most of the respondents had positive cultural values and engaged in stunting prevention well, totaling 36 respondents (33\%). This research is in line with the research conducted by Cahyani et al. [36] and Illahi and Muniroh [37]. The study stated that there is a significant relationship between cultural factors and the incidence of stunting because there is a culture in place that does not support the provision of nutrition to children, referring to mothers who tend to follow the recommendations of their parents. Besides that, there are several socio-cultural nutrition-related practices engaged in by the Madurese ethnic group, which can lead to stunting. Among others, these include dietary restrictions for pregnant women, the children not receiving their immunizations, giving pre-lacteal feeding to newborns, and providing complementary foods with early breastfeeding.

Parent's cultural values that are not supported by maternal care because they are following the recommendations from parents, grandmothers, or grandfathers. Even though this is against the suggestions made concerning the child's health, the parents are considered to have experience in childcare, so all recommendations must be followed. The respondents provided early complementary breastfeeding; this is because the child is fussy and the respondent thinks that the child is hungry. Therefore, they are given complementary breastfeeding early. The culture means that it is believed by the respondents that there are some dietary restrictions for children, pregnant women, and nursing mothers. This is supported by the demographic data which show that there were 38 families living with their extended families. These respondents often follow orders from their parents. This cultural value goes against the suggestions for the child's optimal health and it is one of the factors that influence the occurrence of stunting.

The research results show that there is a significant relationship between parenting patterns and stunting prevention. Most of the respondents practiced good care with positive stunting prevention. This research is in line with the research conducted by Karaki et al. [38], which states that there is a significant relationship between maternal parenting and problematic eating behaviors in children. The research conducted by Loya and Nuryato [5] states that incorrect feeding patterns in relation to toddlers have the potential to cause stunting. The research conducted by Surani and Susilowati [39] also states that there is a significant relationship between the patterns when fulfilling basic needs, which include exclusive breastfeeding, complementary feeding, and emotional needs (early), the early initiation of breastfeeding, and early stimulation with stunting events in toddlers. Good parenting practices can overcome two crucial problems, stunting, and stimulation. Parenting programs could increase the mother's knowledge about child development and the necessary diversity of child feeding [7].

The researchers assume that parenting is related to the prevention of stunting. Good parenting patterns will prevent stunting. Parenting when giving food to their children greatly affects the nutritional status of the child. This will later affect the child's growth and health. If the parenting is done correctly, all of the needs of the child will be met and the child will grow optimally, meaning that stunting can be avoided [40]. Parenting is not only about providing food, environmental sanitation, and giving them the appropriate immunizations. The parents' affection also affects their child's growth and development. The need for compassion develops the child's love, spirituality, and independence and meets the need for security and comfort while providing a sense of belonging and independence [41]. The parents' affection will affect the process of growth and development of the children. If the parents always give them love and attention, this will make the children comfortable and close to their parents. Parental love is fundamental, especially when feeding children. A mother must understand the child's appetite and be attentive and patient when providing food to the child. This will build intimacy between the mother and child so then the child will eat well. The food will be eaten, meaning that the nutritional needs of the child will be fulfilled, which will avoid stunting [6]. Good sanitation and a hygienic environment will help the child's growth process optimally. If the home environment is always clean, the chances of the child getting infected will be minimal, so then the child will always be healthy and the child's growth will not be disturbed [10]. Forms of immunization also need to be given regularly to improve the child's immune system to protect them from all kinds 
of disease. The poor parenting that is still carried out by some of the respondents includes not giving them exclusive breastfeeding until the child is 2 years old, the mother not forcing the child when the child does not want to eat, and the mother only cleaning the house when the house looks dirty.

This study shows the demographic and cultural factor that contributed to stunting in Madura, Indonesia. However, the study has limitations to conduct multivariate analysis to assess various independent variables. The national data to observe the stunting factors could be considering getting the wider information.

\section{Conclusions}

This study found that insufficient knowledge was significantly associated with lower prevention of stunting. Positive behavior, in an effort to prevent stunting, results in a unidirectional relationship. In addition, the respondents with a sufficient income were able to meet the food needs of their children which prevented stunting. The cultural values inherent in the respondents also have a significant relationship with stunting prevention behavior. Parenting is a variable related to stunting prevention. For stunting prevention, apart from requiring direct action from the parents, assistance, and support from the government and health workers is needed to maximize stunting prevention. This research can be used as basic information to make new policies to prevent stunting.

\section{References}

1. Masrul ES. Faktor-faktor yang berhubungan dengan kejadian stunting pada anak usia 24-59 bulan di wilayah kerja puskesmas andalas kecamatan padang timur kota padang tahun 2018 eko. J Kesehat Andalas. 2018;7(2):275-84. https://doi.org/10.25077/ jka.v7.i2.p275-284.2018

2. Ministry of Health of the Republic of Indonesia. Indonesian Health Profile for 2017. Jakarta: Ministry of Health of the Republic of Indonesia; 2018. https://doi.org/10.25133/jpssv27n1.003

3. Dinas Kesehatan Provinsi Jawa Timur. Profil Kesehatan Madura 2018. Madura: Dinas Kesehatan Provinsi Jawa Timur; 2018.

4. Dinas Kesehatan Kabupaten Pamekasan. Profil Kesehatan Kabupaten Pamekasan. Pamekasan: Dinas Kesehatan Kabupaten Pamekasan; 2018

5. Loya RR, Nuryanto N. Pola asuh pemberian makan pada balita stunting usia 6-12 bulan di kabupaten sumba tengah nusa tenggara timur. J Nutr Coll. 2017;6(1):83-95. https://doi. org/10.14710/jnc.v6i1.16897

6. Yudianti $\mathrm{Y}$, Saeni RH. Pola asuh dengan kejadian stunting pada balita. J Kesehat Manarang. 2016;2(1):21-5. https://doi. org/10.33490/jkm.v2i1.9

7. Nutrition and Metabolic Diseases Coordination Work Unit.
Indonesian Pediatric Association, Recommendation Evidencebased Feeding Practices for Infants and Toddlers in Indonesia to Prevent Malnutrition. Indonesia: Ikatan Dokter Anak Indonesia; 2015.

8. Picauly I, Toy SM. Analisis determinan dan pengaruh stunting terhadap prestasi belajar anak sekolah di kupang dan sumba tmur, NTT. J Gizi Pangan. 2013;8(1):55-62. https://doi. org/10.25182/jgp.2013.8.1.55-62

9. Latifah E, Hastuti D, Latifah M. Pengaruh pemberian ASI dan stimulasi psikososial terhadap perkembangan sosial-emosi anak balita pada keluarga ibu bekerja dan tidak bekerja. J IImu Kel Konsum. 2010;3(1):35-45. https://doi.org/10.24156/ jikk.2010.3.1.35

10. Millennium Challenge Account Indonesia. Stunting and the Future of Indonesia. Jakarta: Millennium Challenge Account Indonesia; 2013.

11. Widanti YA. Prevalensi, faktor risiko, dan dampak stunting pada anak usia sekolah. J Teknol Ind Pangan. 2017;1(1):1512. https://doi.org/10.20884/1.jgps.2018.2.1.512

12. Aramico B, Sudargo T, Susilo J. Hubungan sosial ekonomi, pola asuh, pola makan dengan stunting pada siswa sekolah dasar di kecamatan lut tawar, kabupaten aceh tengah. Indones J Nutr Diet. 2016;1(3):121-30. https://doi.org/10.21927/ ijnd.2013.1(3).121-130

13. Stephanie S. Slovin's Formula: What is it and When do I use it? StatistikHowto;2021.Availablefrom:https://www.statisticshowto. com/how-to-use-slovins-formula/\#: :text=Slovins's $\% 20$ formula $\% 20$ is $\% 20$ used $\% 20$ to, sample $\% 20$ size $\% 20$ from $\% 20 a \% 20$ population.\&text=Statistics $\% 20$ is $\% 20 a \% 20$ way\%20of,because $\% 20$ of $\% 20$ money\%20or\%20time.

14. Health Ministry of Republic Indonesia. Age Classification Based on Category. Jakarta, Indonesia: Ditjen Yankes; 2009.

15. Setiya T. 7 Types of Family in Indonesia; 2017. Available from: https://www.factsofindonesia.com/types-of-family-in-indonesia. [Last accessed on 2020 Jan 07].

16. Statute of the Republic of Indonesia. National Education System. Indonesia: Statute of the Republic of Indonesia; 2003.

17. Rutstein SO, Rojas G. Guide to DHS Statistics; 2006. Available from: https://www.ophi.org.uk/wp-content/uploads/OPHIHDCA-SS2012-Guide_DHS_Statistics.pdf

18. Croft TN, Marshall AM, Allen CK. Guide to DHS Statistics (Version 2). Rockville, Maryland, USA: ICF International; 2018.

19. Demographic Health Survey, "Wealth Quintiles," USAID; 2018. Available from: https://www.dhsprogram.com/data/Guideto-DHS-Statistics/Wealth Quintiles.htm. [Last accessed on 2020 Jun 25]

20. Demographic Health Survey. DHS Model QuestionnairePhase 7 (English, French); 2015. Available from: https:// www.dhsprogram.com/publications/publication-dhsq7dhs-questionnaires-and-manuals.cfm. [Last accessed on 2020 May 15].

21. Mediarti D, Rosnani R, Sukartini T, Arifin H, Kurniawati $Y$ Coverage and factors associated with complete polio vaccination among Indonesian children aged 0-18 months. Child. Youth Serv Rev. 2020;118:105399. https://doi.org/10.1016/j. childyouth.2020.105399

22. Kemenkes. Buletin Stunting. Kementeri. Vol. 301. Indonesia: Kesehat, Republik Indones; 2018. p. 1163-78.

23. World Health Organization. Childhood Stunting: Challenges and Opportunities. Geneva: World Health Organization; 2013.

24. Sundari E, Nuryanto N. Hubungan asupan protein, seng, zat besi, dan riwayat penyakit infeksi dengan Z-score $\mathrm{Tb} / \mathrm{U}$ pada balita. J Nutr Coll. 2016;5(4):520-9. https://doi.org/10.14710/jnc. v7i4.22277

25. Manumbalang ST, Rompas S, Bataha YB. Hubungan pola asuh dengan status gizi pada anak di taman kanak-kanak kecamatan 
pulutan. J Keperawatan UNSRAT. 2017;5:1-8. https://doi. org/10.21831/jpa.v2i1.3031

26. Christiari AY, Syamlan R, Kusuma IF. Hubungan pengetahuan ibu tentang stimulasi dini dengan perkembangan motorik pada anak usia 6-24 bulan di kecamatan mayang kabupaten jember. Pustaka Kesehatan. 2013;1(1):1-4. https://doi.org/10.24114/ jkss.v16i32.11927

27. Aridiyah NA, Rohmawati FO. Faktor-faktor yang mempengaruhi kejadian stunting pada anak balita di wilayah pesedaan dan perkotaan. Pustaka Kesehat. 2015;3(1):164-70. https://doi. org/10.33143/jhtm.v4i1.994

28. Kassie GW, Workie DL. Determinants of under-nutrition among children under five years of age in Ethiopia. BMC Public Health. 2020;20:1-11. https://doi.org/10.21203/rs.2.17004/v4

29. Pormes $A$, Rompas WE, Ismanto S. Hubungan pengetahuan orang tua tentang gizi dengan stunting pada anak usia 4-5 tahun di tk malaekat pelindung manado. J Keperawatan UNSRAT. 2014;2(2):136. https://doi.org/10.36049/jgk.v8i1.136

30. Olsa ED, Sulastri D, Anas E. Relationship between mother's attitudes and knowledge of stunting in children entering new elementary school in Nanggalo district. J Kesehat Andalas. 2018;6(3):523-9. https://doi.org/10.25077/jka.v6i3.733

31. Septamarini R, Widyastuti RG, Purwanti N. Hubungan pengetahuan dan sikap responsive feeding dengan kejadian stunting pada baduta usia 6-24bulan di wilayah kerja puskesmas bandarharjo, Semarang. J Nutr Coll. 2019;8(1):9-20. https://doi. org/10.14710/jnc.v8i1.23808

32. Utami RA, Setiawan A, Fitriyani P. Identifying causal risk factors for stunting in children under five years of age in South Jakarta, Indonesia. Enferm Clin. 2019;29(2):6-11. https://doi. org/10.1016/j.enfcli.2019.04.093 PMid:31311736

33. Aryastami NK, Shankar A, Kusumawardani N, Besral B, Jahari $A B$. Low birth weight was the most dominant predictor associated with stunting among children aged 12-23 months in Indonesia. BMC Nutr. 2017;3:1-6. https://doi.org/10.1186/ s40795-017-0130-x

34. Beal T, Tumilowicz A, Sutrisna A, Izwardy D, Neufeld LM. A review of child stunting determinants in Indonesia. Matern Child Nutr. 2018;14(4):e12617. https://doi.org/10.1111/ mcn.12617 PMid:29770565

35. Cetthakrikul N, Topothai C, Suphanchaimat R, Tisayaticom K. Childhood stunting in Thailand: When prolonged breastfeeding interacts with household poverty. BMC Pediatr. 2018;18:1-9. https://doi.org/10.1186/s12887-018-1375-5

36. Cahyani R, Yunitasari VU, Indarwati E. Dukungan sosial sebagai faktor utama pemberian intervensi gizi spesifik pada anak usia 6-24 bulan dengan kejadian stunting berbasis transcultural nursing. Pediomaternal Nurs J. 2019;5(1):77-88. https://doi. org/10.20473/pmnj.v5i1.12410

37. Illahi RK, Muniroh L. Gambaran sosio budaya gizi etnik madura dan kejadian stunting balita usia 24-59 bulan di Bangkalan. Media Gizi Indones. 2018;11(2):135. https://doi.org/10.20473/ mgi.v11i2.135-143

38. Karaki M, Kundre KB, Karundeng R. Hubungan pola asuh ibu dengan perilaku sulit makan pada anak usia prasekolah (3-5 tahun) di taman kanak-kanak desa palelon kec. modoinding minahasa selatan. J Keperawatan UNSRAT. 2016;4(1):1053. https://doi.org/10.36085/jkmu.v8i2.1053

39. Surani E, Susilowati E. The relationship between fulfilment of basic needs with the incidence of stunting in toddlers. J Ners. 2020;15(1):26. https://doi.org/10.20473/jn.v15i1.17286

40. Pratiwi E, Masrul TD, Yerizel M. Hubungan pola asuh ibu dengan status gizi balita di wilayah kerja puskesmas belimbing kota padang. J Kesehat Andalas. 2016;5(3):661-5. https://doi. org/10.25077/jka.v5i3.595

41. El Sinta Bustami L, Insani AA, Yulizawati Y. Hubungan pola pemenuhan kebutuhan dasar bayi dalam pemberian ASI terhadap perkembangan bayi. Trik Tunas Ris Kesehat. 2018;8(2):77-81. 